\title{
Social Associations and Dominance of Individuals in Small Herds of Cattle
}

\author{
Norman R. Harris, ${ }^{1}$ Douglas E. Johnson, ${ }^{2}$ Neil K. McDougald, ${ }^{3}$ and Melvin R. George ${ }^{4}$
}

Authors are ${ }^{1}$ Assistant Professor, School of Natural Resources and Agricultural Sciences, University of Alaska Fairbanks, Palmer Research and Extension Center, 533 E. Fireweed Ave, Palmer, AK 99645-6629; ${ }^{2}$ Professor, Department of Range Ecology and Management, Oregon State University, Corvallis, OR 97331-2218; ${ }^{3}$ Farm Advisor, University of California Cooperative Extension, Madera, CA 93637; and ${ }^{4}$ Project Director/Extension Range Specialist, University of California Davis, Agronomy and Range Science, Davis, CA 95616-8515.

\begin{abstract}
A series of 6 daylight observations was made each summer and again each winter over 2 years to map cattle distribution on a California foothill pasture. Sixty animals were used in the study with no animals appearing in $>1$ observation series. During daylight hours, small herds of cows containing between 14 and 16 animals were scan-sampled and videotaped every 15 minutes. A global positioning system was used to record the position of the camera to aid in accurately locating individual animals. Animal locations and individual identifications were then entered into a geographic information system (GIS) by on-screen digitizing using color orthophotographs. Animal positions were determined to be within $5 \mathrm{~m}$ of their true location. Association software, ASSOC1, was used to analyze animal positions to determine cattle subgroups and herd units. This position-based grouping was compared with observation-based grouping by researchers. Direct observation also identified dominant herd members. Older animals, up to 16 years of age, were generally dominant over younger animals, and subgroups tended to be composed of animals of similar age. The size of naturally occurring subgroups was between 3 and 6 animals. Some animals exhibited independence in their actions and behaviors compared with subgroup members. ASSOC1 produced grouping results consistent with direct observations. However, accurate interpretation of the ASSOC1 results depended on direct observational data. ASSOC1 identified close association patterns in 3 of the observations that defined the dominant animals in the herd. Forage availability and thermoregulatory needs influenced the distance between associated subgroup members. Distance between animals decreased when animals sought shade in summer or shelter in winter. Computer analysis of spatial data from GPS collars may be able to determine the social structure and identify dominant animals in herd situations. Incorporating knowledge of cattle social behavior should improve management of cattle on the range.
\end{abstract}

\section{Resumen}

Una serie de 6 observaciones diurnas se hizo cada verano y se repitió cada invierno durante 2 años, para mapear la distribución del ganado en una pradera de piedemonte de California. En el estudio se utilizaron 60 animales, sin que los animales aparecieran en más de una de las series de observaciones. Durante las horas diurnas, pequeños hatos de vacas, entre 14 al 16 animales, se examinaron visualmente y se filmaron cada 15 minutos. Para registrar la ubicación de la cámara se uso un Sistema de Posicionamiento Global, como apoyo de la localización certera de los animales individuales. Las localizaciones de los animales y las identificaciones individuales de ellos se introdujeron a un Sistema de Información Geográfica (GIS) mediante la digitalización en pantalla usando ortofotos a color. Las posiciones de los animales se determinaron con una exactitud de cinco metros de su posición real. El programa computacional de asociación ASSOC1 se uso para analizar las posiciones de los animales y determinar los subgrupos de animales y unidades de hato. Esta agrupación en base a la posición se comparó con la agrupación basada en observaciones realizadas por los investigadores. Las observaciones directas también identificaron los miembros dominantes de los hatos. Los animales viejos, hasta de 16 años, generalmente dominaron a los animales jóvenes, y los subgrupos tendieron a estar compuestos de animales de la misma edad. El tamaño de los subgrupos que se forman naturalmente estuvo entre 3 y 6 animales. Algunos animales mostraron independencia en sus acciones y comportamiento en comparación con los miembros del subgrupo. EL ASSOC1 produjo resultados de agrupamiento consistentes con las observaciones directas. Sin embargo, la interpretación correcta de los resultados del ASSOC1 depende de los datos de observación directa. El ASSOC1 identificó patrones de asociación muy similares en tres de las observaciones que definieron los animales dominantes del hato. La disponibilidad de forraje y las necesidades termoregulatorias influenciaron la distancia entre los miembros asociados a los subgrupos. La distancia entre animales diminuyó cuando buscaban sombra en verano o abrigo en invierno. El análisis computarizado de los datos espaciales del GPS puede ser capaz de determinar la estructura social e identificar los animales dominantes en los hatos. La incorporación del conocimiento del comportamiento social del ganado debe mejorar el manejo del mismo en el pastizal.

Key Words: association software, nearest neighbor, social structure, spatial distribution

Research was funded in part by USDA Grant 00-521039646, University of California Cooperative Extension, Oregon Experiment Station Oregon State University, and the Alaska Agricultural and Forestry Experiment Station University of Alaska Fairbanks. SNRAS Publication 2005-014.

Use of trade names is for the benefit of the reader and does not indicate endorsement by the project, the University of Alaska or the Alaska Agricultural and Forestry Experiment Station. At the time of the research, Harris was a post-doctoral fellow, Dept of Rangeland Resources, Oregon State University, Corvallis, OR.

Correspondence: Norman R. Harris, University of Alaska Fairbanks, Palmer Research and Extension Center, 533 E. Fireweed Ave, Palmer, AK 99645-6629. Email: pfnrh@uaa.alaska.edu

Manuscript received 21 August 2005; manuscript accepted 25 March 2007. 


\section{INTRODUCTION}

Many studies have shown that free-ranging cattle use riparian areas more than upland areas (Wagnon 1967; Bryant 1982; Roath and Krueger 1982a; Kauffman et al. 1983; Gillen et al. 1984). Livestock grazing has been implicated in stream-bank erosion (Kauffman et al. 1983) and as a possible source of bacterial contamination for urban watersheds (Tate et al. 2000). Knowledge of spatial and temporal factors that affect cattle distribution is critical for effective management of livestock in these ecosystems (Senft et al. 1987). Previous reviews examining mechanisms for predicting cattle distribution (Coughenour 1991; Bailey et al. 1996) emphasized environmental and physical factors. Other researchers (Smith 1988; Harris 2001) used an animal's response to physiological needs to predict movements upon the landscape. Although there are references to the effects of social behavior in those articles, that information was not incorporated as a component of suggested predictive models.

Rangeland cattle form loosely organized herd units that reflect a social structure with multiple layers. At an upper level of organization, cattle form stable social subgroups (Sowell et al. 1999). Stricklin (1983) stated that spatial relationships among individuals within groups are a key to understanding the social structures of groups. Social associations can be determined by the spatial arrangement of animals in a herd situation and the amount of time an animal spends in close proximity to another animal (Stricklin 1983; Lazo 1994; Weber et al. 2001). Reinhardt and Reinhardt (1981) documented close and long-lasting grazing associations in a herd over 5 years. Associated animals were usually biologically related on the matrilineal line (Reinhardt and Reinhardt 1981; Stricklin 1983; Lazo 1994). Previously, researchers (Roath and Krueger 1982b; Howery et al. 1996) have shown that subgroups demonstrated home-range fidelity. Therefore, will predictive models that fail to address the social aspects of cattle herds work adequately?

Some distribution studies are based upon the general observation of entire herds of cattle (Moorefield and Hopkins 1951; Peterson and Woolfolk 1955; Roath and Krueger 1982b; Howery et al. 1996; Bailey et al. 2001; Porath at al 2002). Herd observations often lack data on individual cows, which make associations among animals difficult or impossible to detect. In the past, other livestock distribution studies were often based on observations of a few animals (Wagnon 1963; Malechek and Smith 1976; Bryant 1982; Senft et al. 1983; Marlow and Pogacnik 1986). The social influence of neighboring cows often went undetected in these types of studies.

In recent years, use of radiotelemetry collars has allowed researchers to track free-ranging cattle over large areas (Pinchak et al. 1991). Even more recently, Global Positioning System (GPS) receivers coupled with data loggers fitted onto collars are used to track animals (Ganskopp 2001; Bailey and Weller 2007). Although GPS collars can collect large amounts of positional information at a fine resolution $(3-5 \mathrm{~m})$, the cost of commercially available collars has limited their use to only a few animals out of an entire herd. In the future, advances in technology will reduce the cost (Clark et al. 2006), but until then, the questions become, do the actions of one or a few animals accurately reflect herd actions, and how variable are subunits or individuals within a herd? Hull et al. (1960) found highly significant differences in individual animal behavior patterns over a 24-hour period and stated that several animals (their study included 4) needed to be observed to obtain reliable estimates of animal behavior. Individual animal activity may also reflect movement of a subgroup and, therefore, be atypical for the herd (Oberosler et al. 1982).

Sato (1982) reported that cattle could be grouped into 1 of 3 social classes in their movements within a herd during grazing: leaders, followers, and independent animals. Dominant animals in the social order were usually leaders. Lowranking animals were either followers or independent animals. Although independent animals did not always follow the group, at other times they would associate with it. Leaders were often involved in grazing associations with specific cows (Reinhardt and Reinhardt 1981). Bailey (1995) found that leaders consistently selected patches for grazing by the herd, and lower status animals followed the leader's example. Movement of a herd seems to be the result of active movement by dominant animals and a general consensus by lower-ranking animals to follow (Sato 1982). Therefore, the location of an independent animal may or may not be representative of general herd movements.

Cow hierarchies can be linear, or often, triadic in nature. In a triadic hierarchy, female A dominates over B; B is dominant over C, but C is dominant over A (Schein and Fohrman 1955). One main difference between male and female social groups is permanence of status among females. Dominance among cows seems to be based on mutual familiarity within a stable group (Honoré and Klopfer 1990). Takeda et al. (2000) found herd members most often chose farm mates as nearest neighbors, rather than nonfarm mates, in a mixed-herd situation. Beilharz and Zeeb (1982) reported that dominance patterns are learned when animals are young and that the pattern persists as they age. Mature animals generally have clear unidirectional dominance relationships where 1 animal is always the dominant member, whereas young animals have bidirectional relationships, where dominance can shift back and forth between animals (Stricklin and Mench 1987).

Because of management actions, such as culling, mixing of herds or animal purchases, herds are not stable groups. How this mixing of animals affects herds and the composition of social subgroups is unknown (Mench et al. 1990). A better understanding of herd dynamics can make predictive distribution models based on GPS or telemetry data more reliable.

Our study was designed to analyze the spatial and temporal grouping of cattle in small herd situations. One objective was to determine the natural size of cattle subgroups that occurs through free and unrestricted association of animals. A second objective was to determine herd dominance hierarchies, identify the factors associated with social dominance among these herds, and examine the effect of dominance on spatial arrangement of animals. A third objective was to compare observer-delineated subgroups with a computerized spatialgrouping algorithm to determine whether subgroup membership could be identified using only spatial data. We used association matrices based on cow positions and the association software package, ASSOC1, developed by Keith Weber (Weber et al. 2001), to analyze associations and social dynamics within the herd. 


\section{MATERIALS AND METHODS}

\section{Site Description}

This study was conducted on the San Joaquin Experimental Range (SJER; lat $37^{\circ} 06^{\prime} 36^{\prime \prime} \mathrm{N}$, long $\left.119^{\circ} 43^{\prime} 27^{\prime \prime} \mathrm{W}\right)$ located along State Highway 41 approximately $30 \mathrm{~km}$ north of Fresno, California. The SJER encompasses 1837 ha and has been a research facility operated by the US Department of Agriculture (USDA) Forest Service since 1934. The SJER is located on the east side of the San Joaquin Valley within the oak savanna vegetation type in the Sierra Nevada foothills. Our study used range-unit 72 on the facility, which encloses 75.2 ha. The elevation of our study unit ranges from 374 to $451 \mathrm{~m}$ above sea level with tree and shrub canopy covering approximately $30 \%$ of the area. The annual grasses, soft chess (Bromus hordeaceus L.) and foxtail fescue (Vulpia myuros [L.] C. Gemlin), and 2 broadleaf filaree species (Erodium spp.) are the principal components of the available forage. These species constitute between $75 \%$ and $95 \%$ of annual herbaceous production. Some swale areas support large populations of bur-clover (Medicago polymorpha L.) and Bermuda-grass (Cynodon dactylon [L.] Pers.). The research site is described in detail by Harris (2001).

\section{Experimental Design}

The data presented in this article are part of an overall study of animal movement as determined from a series of 6, 24-hour observations (observation day) made each summer (July) and again each winter (January) over the 2-year duration of the study, from June 1997 until January 1999. Observation days were separated by 3-7 days, during which we changed the availability of water between 2 locations and/or supplied a protein supplement (Crystalyx 20\% CP). These treatments were part of a simultaneous study looking at the influence of water and protein supplement locations on the spatial distribution of cattle and ascertaining the effects those management actions had on the overall animal distribution on the landscape. We used 2 types of observations in our study: daylight and dark. During daylight hours, we scan-sampled using a video camera to collect data on individual cattle positions. During the hours at night, when we could not reliably identify individual animals because of darkness, we would note the general herd location by drawing polygons on orthophotos delineating herd spatial dispersion. The analysis featured in this article uses only the daylight observations of individual cows.

\section{Cattle}

Cows were randomly selected 4 days before each observation series began from the larger herd consisting of approximately 250 animals. Forty to fifty cows that were available for use were brought into a holding area and 14-16 cows (stocking density $=4.70-5.37$ ha $\cdot$ animal unit ${ }^{-1}$ ) were randomly selected for use in each trial by SJER staff. Cows were weighed, and their condition was scored by experienced observers. In all, 60 animals were used in this study (Table 1) with no animals participating in $>1$ observation series. All animals had previously grazed the range unit. Cows were of mixed breed with an average weight of $513 \mathrm{~kg}$. Their ages ranged from 2 to
16 years with an average of 7 years. The oldest cow was 4 years older than the next oldest cow. The largest age group was 4year-olds with 12 animals $(20 \%)$. In most cases, the exact lineage of the cows is unknown, so cows were grouped by visible characteristics into representative types. The Black Baldy crossbreed was the predominant type with 21 animals (35\% of total), followed by Black Angus at 19 animals (32\%). The other types were Brahman and Hereford, each with 5 animals $(8 \%)$, and Charolais and Red Angus, each with 3 animals $(5 \%)$. One animal was known to be a Red Gelbvieh $(2 \%)$ and 3 animals $(5 \%)$ could not be reliably placed into any breed type. It is the practice at the SJER to dehorn animals that exhibit the tendency, and only 5 animals possessed any horns: 3 cows had only 1 misshapen horn resulting from regrowth after dehorning, and 2 replacement cows possessed a full set.

\section{Forage Sampling}

Standing crop was measured in the middle of each observation series except for the summer of 1998 when it was measured at the end of the observation series because of inclement weather during the study. Forage was sampled at 22 locations stratified across representative range sites, delineated using a site classification developed by Bentley and Talbot (1951). At each location, 2, 0.093- $\mathrm{m}^{2}$ (1 foot ${ }^{2}$ ) plots were clipped at ground level. Clipped vegetation was weighed, dried in an oven at $55^{\circ} \mathrm{C}$ for 24 hours, reweighed, and ground to pass through a 1-mm screen. Samples were then analyzed for crude protein using the Kjeldahl method and acid-digestible fiber (ADF, Van Soest 1982).

\section{Cattle Observations and Spatial Data Collection}

During daylight hours, observers videotaped all cows that they could locate every 15 minutes (scan sampled) to record cow identity and activity. In cases where the herd fragmented or only subgroups of cows were found, observers followed the group that contained the greatest number of cows. The video camera was zoomed in and out on each animal so that distinctive landscape features could later be used to position animals. Additionally, for each observational scan (every 15 minutes) the position of the videographer was recorded using a Trimble Pathfinder ProXR differential global positioning system (DGPS). The positions of the videographer were differentially postprocessed to produce points with an accuracy $<2 \mathrm{~m}$. Additional information, such as weather conditions at the site, cow grouping, and verbal positional cues, were recorded via the audio track.

Later, in the laboratory, the videotapes of daylight observations were viewed. Using the corrected GPS locations of the videographer supplemented by the verbal positional cues, animal positions, activities, and identities for each cow were converted to digital format through on-screen digitizing using color orthophotos with 0.25 -m resolution (positional accuracy $2.2 \mathrm{~m}$ based on 100 stratified-random points). Because this area has many well-defined and relatively small landscape features, such as rock outcrops, dry creek beds, swales, trees, and fence lines, we could digitize the positions of cows with high accuracy. To evaluate the spatial accuracy of our method, we videotaped 100 random cow positions and immediately marked the locations with flagging tape. Flagged positions were 
Table 1. Cow identification numbers, age, breed, presence of horns, weight, weight rank, age rank, and dominance rank of animals in the study. Dominance was only determined for positions 1, 2, and 3. All unranked animals are shown by the number "4" or independent status.

\begin{tabular}{|c|c|c|c|c|c|c|c|c|c|c|c|}
\hline \multicolumn{6}{|c|}{ Summer 1997} & \multicolumn{6}{|c|}{ Winter 1998} \\
\hline $\begin{array}{l}\text { Cow } \\
\text { id }\end{array}$ & $\begin{array}{c}\text { Age }(y r) \\
\text { breed }^{1}\end{array}$ & $\begin{array}{l}\text { Body weight } \\
(\mathrm{kg})\end{array}$ & $\begin{array}{l}\text { Weight } \\
\text { rank }\end{array}$ & $\begin{array}{l}\text { Age } \\
\text { rank }\end{array}$ & $\begin{array}{l}\text { Dominance } \\
\text { rank }\end{array}$ & $\begin{array}{l}\text { Cow } \\
\text { id }\end{array}$ & $\begin{array}{c}\text { Age }(\mathrm{yr}) \\
\text { breed }\end{array}$ & $\begin{array}{l}\text { Body weight } \\
(\mathrm{kg})\end{array}$ & $\begin{array}{l}\text { Weight } \\
\text { rank }\end{array}$ & $\begin{array}{l}\text { Age } \\
\text { rank }\end{array}$ & $\begin{array}{l}\text { Dominance } \\
\text { rank }\end{array}$ \\
\hline 0471 & (16) $\mathrm{Br}$ & 533 & 4 & 1 & 1 & 9036 & (9) $A n$ & 544 & 3 & 3 & 1 \\
\hline 7123 & (10) An & 546 & 3 & 3 & 2 & 0190 & (8) An & 583 & 1 & 4 & 2 \\
\hline 3104 & (4) $\mathrm{He}^{2}$ & 489 & 10 & 11 & 3 & 2124 & (6) $\mathrm{He}$ & 486 & 6 & 6 & 3 \\
\hline 7113 & (10) Ba & 503 & 7 & 3 & 3 & 4147 & (4) $R A^{3}$ & 480 & 8 & 9 & 4 \\
\hline 8123 & (9) M & 506 & 6 & 5 & 3 & 4164 & (4) $A n$ & 448 & 11 & 9 & 4 \\
\hline 0008 & (7) $\mathrm{RG}$ & 532 & 5 & 6 & 4 & 4066 & (4) $A n^{3}$ & 412 & 14 & 9 & 4 \\
\hline 0507 & (2) An & 420 & 13 & 13 & 4 & 4184 & (4) An & 384 & 16 & 9 & 4 \\
\hline 0508 & (2) An & 460 & 12 & 13 & 4 & 4106 & (4) An & 397 & 15 & 9 & 4 \\
\hline 1094 & (6) $\mathrm{Ba}$ & 560 & 2 & 8 & 4 & 4067 & (4) $\mathrm{Ba}$ & 428 & 13 & 9 & 4 \\
\hline 4027 & (3) An & 469 & 11 & 12 & 4 & 0001 & (5) $\mathrm{Ch}$ & 432 & 12 & 7 & 4 \\
\hline 0012 & (7) $\mathrm{RA}$ & 497 & 9 & 6 & 4 & 0002 & (5) $\mathrm{Ch}$ & 482 & 7 & 7 & 4 \\
\hline 2142 & (5) $\mathrm{He}^{2}$ & 498 & 8 & 10 & 4 & 4006 & (4) $\mathrm{Ba}$ & 458 & 9 & 9 & 4 \\
\hline 1155 & (6) $\mathrm{Ba}^{2}$ & 585 & 1 & 8 & independent & 4065 & (4) $\mathrm{Ch}$ & 457 & 10 & 9 & 4 \\
\hline 5060 & (12) $\mathrm{Ba}$ & 409 & 14 & 2 & independent & 8056 & (10) $\mathrm{Br}$ & 487 & 5 & 1 & independent \\
\hline \multirow[t]{2}{*}{0503} & (2) An & 409 & 14 & 13 & independent & 0005 & (8) RA & 573 & 2 & 4 & independent \\
\hline & & & & & & 8003 & (10) An & 531 & 4 & 1 & independent \\
\hline \multicolumn{6}{|c|}{ Summer 1998} & \multicolumn{6}{|c|}{ Winter 1999} \\
\hline $\begin{array}{l}\text { Cow } \\
\text { id } \\
\end{array}$ & $\begin{array}{l}\text { Age (yr) } \\
\text { breed }^{1}\end{array}$ & $\begin{array}{c}\text { Body weight } \\
(\mathrm{kg})\end{array}$ & $\begin{array}{c}\text { Weight } \\
\text { rank }\end{array}$ & $\begin{array}{l}\text { Age } \\
\text { rank }\end{array}$ & $\begin{array}{c}\text { Dominance } \\
\text { rank }\end{array}$ & $\begin{array}{c}\text { Cow } \\
\text { id }\end{array}$ & $\begin{array}{c}\text { Age (yr) } \\
\text { breed }\end{array}$ & $\begin{array}{c}\text { Body weight } \\
(\mathrm{kg})\end{array}$ & $\begin{array}{c}\text { Weight } \\
\text { rank }\end{array}$ & $\begin{array}{l}\text { Age } \\
\text { rank }\end{array}$ & $\begin{array}{c}\text { Dominance } \\
\text { rank }\end{array}$ \\
\hline 9084 & (9) An & 693 & 1 & 1 & 1 & 0712 & (12) Ba & 530 & 9 & 1 & 1 \\
\hline 0596 & (8) $\mathrm{Ba}$ & 568 & 8 & 2 & 2 & 7455 & (12) $\mathrm{Br}$ & 550 & 4 & 1 & 2 \\
\hline 1064 & (7) $\mathrm{Ba}$ & 564 & 9 & 6 & 3 & 4096 & (5) An & 503 & 10 & 12 & 3 \\
\hline 2070 & (6) M & 610 & 3 & 7 & 4 & 7080 & (12) $\mathrm{Br}$ & 480 & 11 & 1 & 4 \\
\hline 0373 & (5) Ba & 561 & 11 & 12 & 4 & 6055 & (3) $\mathrm{Ba}$ & 421 & 14 & 14 & 4 \\
\hline 4003 & (4) An & 572 & 6 & 13 & 4 & 7152 & (12) Ba & 570 & 2 & 1 & 4 \\
\hline 5050 & (3) M & 436 & 15 & 15 & 4 & 5078 & (4) An & 438 & 13 & 13 & 4 \\
\hline 0875 & (8) $\mathrm{Ba}$ & 564 & 9 & 2 & 4 & 8029 & (11) $\mathrm{Ba}$ & 549 & 5 & 8 & 4 \\
\hline 2025 & (6) $\mathrm{Ba}$ & 572 & 6 & 7 & 4 & 7115 & (12) Ba & 540 & 7 & 1 & 4 \\
\hline 2044 & (6) $\mathrm{He}$ & 621 & 2 & 7 & 4 & 6066 & (3) $\mathrm{Ba}$ & 453 & 12 & 14 & 4 \\
\hline 2197 & (6) $\mathrm{He}$ & 515 & 13 & 7 & 4 & 8037 & (11) $\mathrm{Br}$ & 548 & 6 & 8 & 4 \\
\hline 0095 & (8) An & 590 & 4 & 2 & 4 & 0035 & (9) An & 564 & 3 & 11 & independent \\
\hline 0486 & (8) An & 524 & 12 & 2 & 4 & 9083 & (10) Ba & 582 & 1 & 10 & independent \\
\hline 4154 & (4) $\mathrm{Ba}$ & 503 & 14 & 13 & independent & 7167 & (12) Ba & 534 & 8 & 1 & independent \\
\hline 2043 & (6) $\mathrm{Ba}$ & 585 & 5 & 7 & independent & & & & & & \\
\hline
\end{tabular}

${ }^{1}$ An indicates Black Angus; Ba, Black Baldy; Br, Brahma; Ch, Charolais; He, Hereford; M, Mixed Breed; RA, Red Angus; RG, Red Gelbvieh.

${ }^{2}$ One horn.

${ }^{3}$ Two horns.

later surveyed with our DGPS unit and compared with positions digitized via the video and digital orthophoto method. The average error for the 100 cow positions tested was $2 \mathrm{~m}$, with no observations being more than $5 \mathrm{~m}$ from their true location.

Observers also assigned animals to subgroups based on the affinity of each animal to other animals because we were often able to track distinct groups for long periods. The social dominance ranking of animals was determined by recording agonistic interactions (bluffing, head butting, and fights) between individuals during the observation days. Observations made when the supplement was present helped us define the herd social structure (Stricklin and Gonyou 1981). Interactions and their outcomes were examined to develop dominance rankings using the methodology developed by Schein and Fohrman (1955). Because these interactions can be very complex, only the top 3 ranked positions for each observational herd were determined. Sometimes 2 or more animals might occupy these ranked positions because the outcomes of agonistic interactions between them could not be reliably predicted.

Our database of daylight observations consists of 14095 animal observations. If all cows had been observed in every daylight-sampling period, there would have been 18704 records. Therefore, we captured $75 \%$ of all possible individual animal observations (Table 2). 
Table 2. Number of daylight observation periods and individual cow observations, also expressed as percentage of individual observations possible, for each observation series.

\begin{tabular}{|c|c|c|c|}
\hline $\begin{array}{l}\text { Observation } \\
\text { series }\end{array}$ & $\begin{array}{l}\text { Number of daylight } \\
\text { observation periods }\end{array}$ & $\begin{array}{c}\text { Number of individual } \\
\text { cow observations }\end{array}$ & $\begin{array}{c}\text { Percentage of } \\
\text { observations possible }\end{array}$ \\
\hline Summer 1997 & 377 & 4110 & 73 \\
\hline Winter 1998 & 247 & 2319 & 59 \\
\hline Summer 1998 & 375 & 5038 & 90 \\
\hline Winter 1999 & 248 & 2628 & 76 \\
\hline Total & 1247 & 14095 & 75 \\
\hline
\end{tabular}

\section{Statistical Analysis}

The association software, ASSOC1, uses association matrices, association patterns, and pattern recognition to approximate the amount of time that each individual cow spent within the proximity, as defined by a user-defined spatial threshold, of every other cow. For example, if a threshold of $25 \mathrm{~m}$ is specified, the program will calculate how much time every-other cow is within $25 \mathrm{~m}$ of each cow. The software then assesses the independence of cow movements and assigns cows to group units based on user-defined temporal (percentage of time) thresholds. ASSOC1 is designed to select one or more association matrices as a herd, or grouping, association template (Table 3), against which, all other individual association matrices are compared. Each individual association matrix is then compared with the herd template to determine percentage of similarity. Herd templates can be formed when 2 animals show any association, even if that association is below the defined temporal threshold. As the spatial threshold is increased, more herd templates are formed until each individual animal has a corresponding herd template showing the percentage of time all other animals are associated with it. Animals that exceed the temporal threshold are flagged with a "yes" in the "Assigned" column of the template, and those animals that do not exceed the threshold are flagged with a "no." The researcher can then examine the resulting herd templates and select relevant templates based on animal associations and the following criteria: 1) the animal showing association with the largest number of other individuals is selected as the group template, and 2) each template is required to identify a mutually exclusive set of individual animals. Templates are selected until one cannot be selected without overlapping individuals already identified by a previous template. Individual animals that demonstrate a similarity (expressed as a percentage) exceeding the temporal threshold are then assigned to that group template.

When the temporal threshold is held constant and the spatial threshold is increased, the frequency of association and percentage of association also increase. At fine spatial thresholds, we are able to distinguish subgroups in the herd. At coarser spatial thresholds, we are able to delineate at what distance the individual animals start to function as a herd unit. A more thorough description of the software and its operation can be found in Weber et al. (2001).

Analysis of the videotapes and notes taken during the observations showed that certain animals had a strong affinity to certain sites and, based on the superimposed treatments, would appear less frequently in 2 out of the 6 observations. Based on those observations, we determined that a $67 \%$
Table 3. Example of a grouping template based on cow 95 generated by ASSOC1 software. This template was generated from data for the summer of 1998 using a spatial threshold of $30 \mathrm{~m}$ and a temporal threshold of $67 \%$. Individual percentage of similarity pattern measures how well an individual's pattern matches the herd template given as a percentage. The assigned values presented as "yes" delineate the subgroup shown in Figure 2.

\begin{tabular}{lccc}
\hline Assigned & Herd template & Individual & $\begin{array}{c}\text { Individual percentage of } \\
\text { similarity pattern }\end{array}$ \\
\hline Yes & 95 & 875 & 100 \\
No & 95 & 1064 & 0 \\
No & 95 & 2025 & 0 \\
No & 95 & 2043 & 0 \\
No & 95 & 2044 & 0 \\
No & 95 & 2070 & 25 \\
No & 95 & 2197 & 0 \\
No & 95 & 5050 & 0 \\
Yes & 95 & 95 & 100 \\
No & 95 & 373 & 0 \\
Yes & 95 & 486 & 75 \\
Yes & 95 & 596 & 100 \\
No & 95 & 4003 & 0 \\
No & 95 & 4154 & 0 \\
Yes & 95 & 9084 & 100 \\
\hline
\end{tabular}

temporal threshold (i.e., animals had to be within the distance threshold $67 \%$ of the time) would work best for animals to be considered associated and to capture most major group interactions. We then ran several iterations of ASSOC1 using $5-\mathrm{m}$ increments as spatial thresholds and various temporal thresholds. We chose this spatial increment because our animal locations were accurate to $\pm 5 \mathrm{~m}$. These runs also indicated that a $67 \%$ temporal threshold worked best on our data. Cattle had to appear in $\geq 33 \%$ of the maximum possible observations to possess enough positional data for meaningful analysis. Three cows from the observations in the winter of 1998 did not meet this criterion and were omitted from the association analysis.

Forage data was analyzed using analysis of variance (ANOVA). The model used to analyze forage parameters included year, season, and interactions. The residual was used as the error term for statistical tests. Tukey's studentized range test (SAS 1998) was used to separate means. Correlation analysis was used to determine the effect of forage biomass on both observed numbers of cattle and threshold distances for animal associations that were first detected using ASSOC1. Cow ages and weights were ranked and compared with dominance rankings through correlation analysis. Spearman's Rank-Order Correlations (Gravetter and Wallnau 1985) were calculated to examine the effect of age and weight on dominance rankings. The Spearman's correlation measures the degree to which a relationship between 2 variables is generally 1 -directional or monotonic. The Spearman's correlation also measures the direction of the trend as either positive or negative.

\section{RESULTS}

During the second year of observations, animals were $60-\mathrm{kg}$ heavier and scored an average of one number higher on body 
Table 4. Forage Characteristics of the San Joaquin Experimental Range, California, for each observation series. Mean comparisons between observation series are indicated by lowercase letters: means within a variable with the same letter do not differ $(P<0.10)$.

\begin{tabular}{|c|c|c|c|c|}
\hline $\begin{array}{l}\text { Observation } \\
\text { series }\end{array}$ & $\begin{array}{c}\text { Dry weight biomass }{ }^{1} \\
\left(\mathrm{kgDM} \cdot \mathrm{ha}^{-1}\right)\end{array}$ & $\begin{array}{l}\text { Protein } \\
(\%)\end{array}$ & $\begin{array}{l}\text { Water } \\
(\%)\end{array}$ & $\begin{array}{l}\text { Acid digestible } \\
\text { fiber }(\%)\end{array}$ \\
\hline \multicolumn{5}{|c|}{ Summer 1997} \\
\hline Mean & $1690 a$ & $6.38 c$ & $11.08 b$ & $49.54 a$ \\
\hline SD & 997 & 1.07 & 8.15 & 7.60 \\
\hline \multicolumn{5}{|l|}{ Winter 1998} \\
\hline Mean & $816 b$ & $13.97 a$ & $78.51 \mathrm{a}$ & $46.55 \mathrm{a}$ \\
\hline SD & 194 & 1.72 & 4.82 & 7.85 \\
\hline \multicolumn{5}{|c|}{ Summer 1998} \\
\hline Mean & $2387 a$ & $6.28 \mathrm{c}$ & $19.10 \mathrm{~b}$ & $49.40 \mathrm{a}$ \\
\hline SD & 1217 & 1.37 & 16.39 & 1.43 \\
\hline \multicolumn{5}{|l|}{ Winter 1999} \\
\hline Mean & $1786 a$ & $11.02 b$ & $75.45 \mathrm{a}$ & $51.07 a$ \\
\hline SD & 386 & 0.18 & 2.12 & 0.90 \\
\hline
\end{tabular}

${ }^{1} \mathrm{kgDM}$ indicates kilograms of dry matter.

condition scores (9 condition scores with scores of 5-7 considered ideal) (Eversole et al. 2000). In the first year, animals scored between 3 and 5 with a mean value of 3.5 , whereas in the second, they scored between 4 and 6 with a mean body condition of 4.5 .

Forage quality, as measured by protein and fiber content (Table 4), was dependent upon season. The quantity of forage available was dependent on weather factors, such as the precipitation and temperature pattern, throughout the year. The major difference between seasons, winter and summer, was in the crude protein content of forage. Winter levels were significantly $(P<0.0001)$ higher than in the summer, $12.2 \pm 1.9 \%$ SD $1.9 \%$ vs. $6.1 \pm 1.4 \%$ SD, as is typical on the California annual grassland. Forage standing crop differed significantly between years $(P<0.001)$. Standing crop for the summer of 1997 was only $70 \%$ of that in summer 1998, whereas standing biomass during the winter of 1998 was $<46 \%$ of that present in the winter of 1999 .

In summer 1998, all animals appeared in $57 \%$ of the scans, whereas in summer 1997 , only $27 \%$ of scans showed all animals. In the winter of 1999 , we located all cows $23 \%$ of the time and, because of calving activity, 13 cows $22 \%$ of the time. In comparison, during the winter of 1998 , only $6.5 \%$ of our observations included all 16 animals. The correlation between percentage of scans showing all animals and forage standing crop was 0.94 .

The numbers and sizes of subgroups based on field observations are shown in Table 5. Our data indicated that the natural size of a stable subgroup of cows in our study area ranged from 3 to 6 animals with $83 \%$ of identified subgroups falling within that range. The mean number of animals in a subgroup was 4 cows. Table 6 shows the results of multiple runs of ASSOC1 using increasing spatial thresholds in 25-m increments for the observation series. For the detailed analysis, spatial thresholds were actually increased in 5-m increments. The correlation between the first association spatial thresholds
Table 5. Subgroup size, the number of subgroups and independent animals in each observation series.

\begin{tabular}{lcccccc}
\hline & \multicolumn{5}{c}{ Subgroup size } \\
\cline { 2 - 5 } $\begin{array}{l}\text { Observation } \\
\text { series }\end{array}$ & $\begin{array}{c}2 \\
\text { Cows }\end{array}$ & $\begin{array}{c}3 \\
\text { Cows }\end{array}$ & $\begin{array}{c}4 \\
\text { Cows }\end{array}$ & $\begin{array}{c}5 \\
\text { Cows }\end{array}$ & $\begin{array}{c}6 \\
\text { Cows }\end{array}$ & $\begin{array}{c}\text { Independent } \\
\text { animals }\end{array}$ \\
\hline Summer 1997 & 1 & & 1 & & 1 & 3 \\
Summer 1998 & & 1 & & 2 & & 2 \\
Winter 1998 & 1 & & & 1 & 1 & 3 \\
Winter 1999 & & 1 & 2 & & & 3 \\
Total & 2 & 2 & 3 & 3 & 2 & 11 \\
\hline
\end{tabular}

for the 4 observation series and forage standing crop was -0.91 . Figure 1 shows the subgroup and herd grouping that were delineated by ASSOC1 at various spatial thresholds from cow positions in the summer of 1997 and demonstrates how group templates were converted to graphical representations. Subgroups and the herd groups delineated by ASSOC1 for the summer of 1998 are shown in Figure 2 for comparison. Subgroups generated from ASSOC1 output matched those delineated by observers in 8 out of 12 cases.

The correlation between dominance rank and age rank (0.72) was higher than the correlation between dominance and weight rank (0.55). When we calculated the Spearman's Rank-Order Correlations, the value for dominance rank and age rank was also higher at 0.65 than the value for dominance and weight at 0.37 .

\section{DISCUSSION}

The difference in body scores of the cows between years was indicative of forage conditions, both in quantity and quality that existed in the months before our observations. Our success in locating and recording cow location and activity was also related to forage conditions during the observation period (Table 2). When forage was abundant, cows traveled in larger groups, and it was easier to see and record all members of the herd (Fig. 3). When there was less forage, animals fragmented into small subgroups, and we were less likely to locate all animals during an observation period, in spite of the fact that animals were using similar sites, and observational frequencies should have been similar. This relationship was supported by the correlation (0.94) between forage standing crop and percentage of scans showing all animals.

The association mean percentage of similarity at the different spatial thresholds is another way of looking at nearest-neighbor distances between animals. The mean percentage of similarity is based on the similarity of all individual cows to all group templates that have been created at that spatial threshold even if there is no similarity between them (Weber et al. 2001). This is the reason the standard deviation is so high at the finer spatial thresholds (i.e., a large number of animals show no association with the templates). If the percentage of similarity is higher at smaller spatial thresholds, then the animals are positioned closer together than if the percentage similarity were lower. The correlation between the first association spatial thresholds for the 4 observation series and forage standing crop was -0.91 , indicating that as forage quantity increased 
Table 6. Association analysis using different spatial thresholds for the observations series. Number individuals associated with group template, mean percentage, and standard deviation of similarity for individuals as compared to group templates are reported. The temporal threshold was maintained at 67 percent.

\begin{tabular}{|c|c|c|c|c|c|c|c|c|}
\hline \multirow[b]{2}{*}{ Parameter } & \multicolumn{8}{|c|}{ Spatial threshold } \\
\hline & $25 \mathrm{~m}$ & $50 \mathrm{~m}$ & $75 \mathrm{~m}$ & $100 \mathrm{~m}$ & $125 \mathrm{~m}$ & $150 \mathrm{~m}$ & $175 \mathrm{~m}$ & $200 \mathrm{~m}$ \\
\hline \multicolumn{9}{|l|}{ Summer 1997} \\
\hline Number associated & 0 & 6 & 8 & 13 & 15 & 15 & 15 & 15 \\
\hline Mean \% Similarity & 0 & 30.9 & 44.3 & 62.9 & 73.8 & 79.0 & 82.1 & 85.8 \\
\hline SD & 0 & 39.0 & 34.5 & 25.2 & 21.5 & 17.4 & 16.3 & 14.6 \\
\hline \multicolumn{9}{|l|}{ Summer 1998} \\
\hline Number associated & 4 & 15 & 15 & 15 & 15 & 15 & 15 & 15 \\
\hline Mean \% Similarity & 22.4 & 74.5 & 91.7 & 97.3 & 99.6 & 100 & 100 & 100 \\
\hline SD & 35.0 & 21.6 & 6.5 & 5.6 & 1.6 & 0.0 & 0.0 & 0.0 \\
\hline \multicolumn{9}{|l|}{ Winter 1998} \\
\hline Number associated & 0 & 1 & 5 & 13 & 13 & 13 & 13 & 13 \\
\hline Mean \% Similarity & 0 & 11.5 & 33.5 & 55.9 & 69.6 & 76.4 & 78.1 & 78.1 \\
\hline SD & 0 & 30.0 & 34.3 & 28.7 & 22.2 & 17.5 & 16.2 & 16.2 \\
\hline \multicolumn{9}{|l|}{ Winter 1999} \\
\hline Number associated & 2 & 4 & 7 & 14 & 14 & 14 & 14 & 14 \\
\hline Mean \% Similarity & 14.3 & 23.3 & 42.2 & 68.7 & 74.3 & 78.2 & 82.3 & 83.8 \\
\hline SD & 33.2 & 38.9 & 31.5 & 18.7 & 17.0 & 16.2 & 15.6 & 15.0 \\
\hline
\end{tabular}

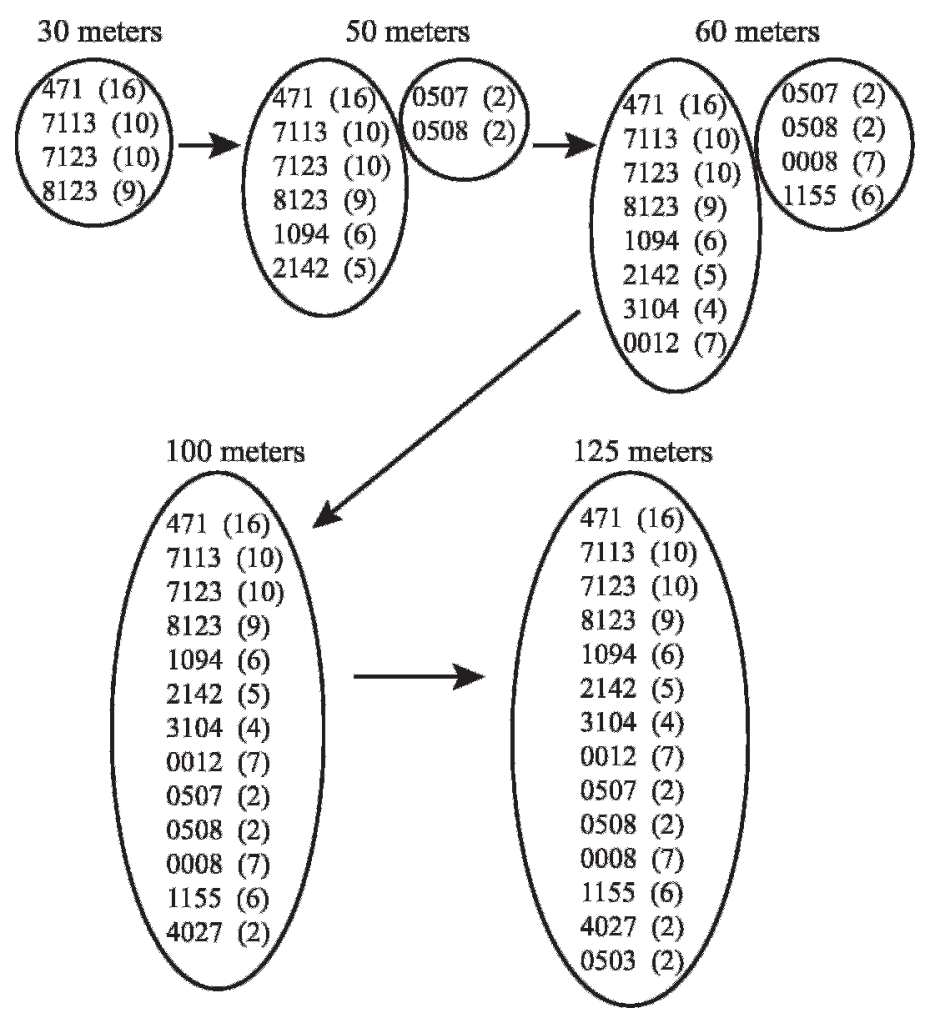

Figure 1. Diagram of subgroups and herd grouping developed from ASSOC1 software association templates for cow positions obtained in summer of 1997. The cow number is provided in each group, and cow age in years is shown in parentheses. Diagram shows spatial thresholds where association templates were formed and demonstrates how animals are added to groups.

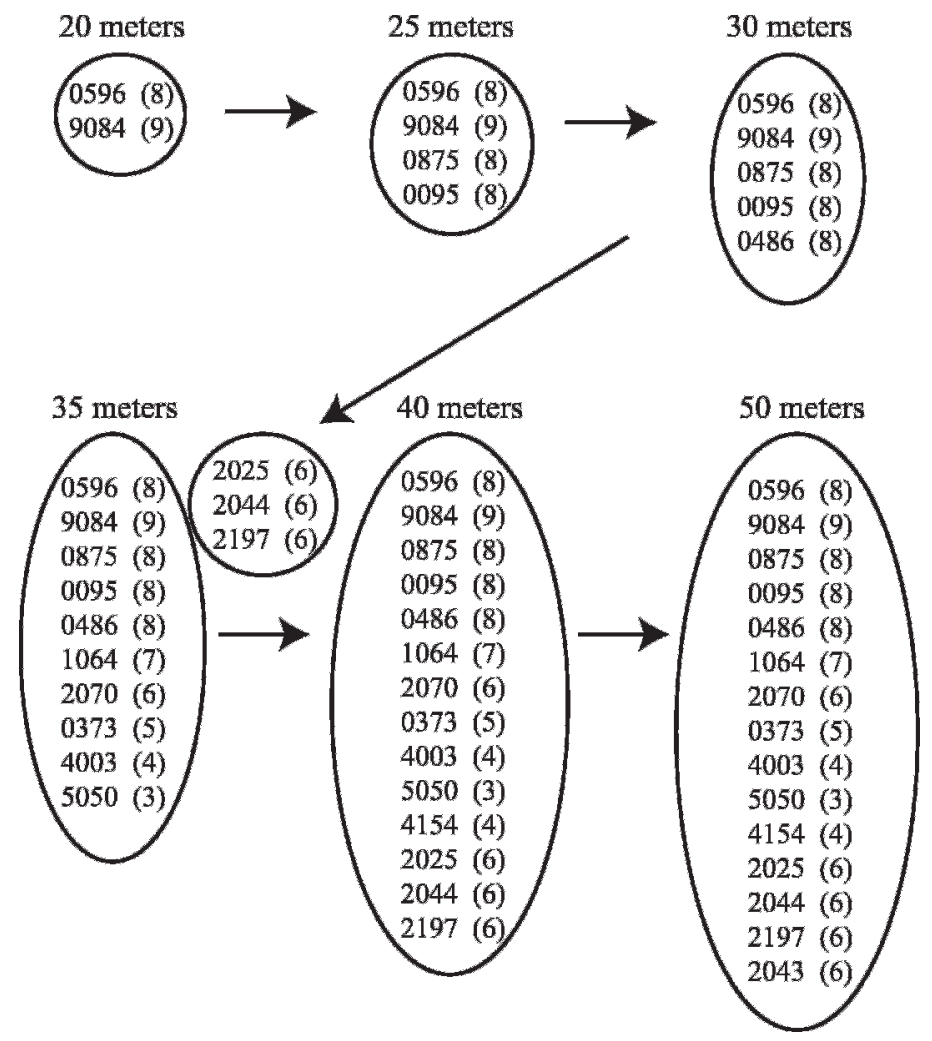

Figure 2. Diagram of subgroups and herd grouping developed from ASSOC1 software association templates for cow positions obtained in summer of 1998. The cow number is provided in each group, and cow age in years is shown in parentheses. Diagram shows spatial thresholds where association templates were formed and demonstrates how animals are added to groups. 
Number of Cows in Observation Periods

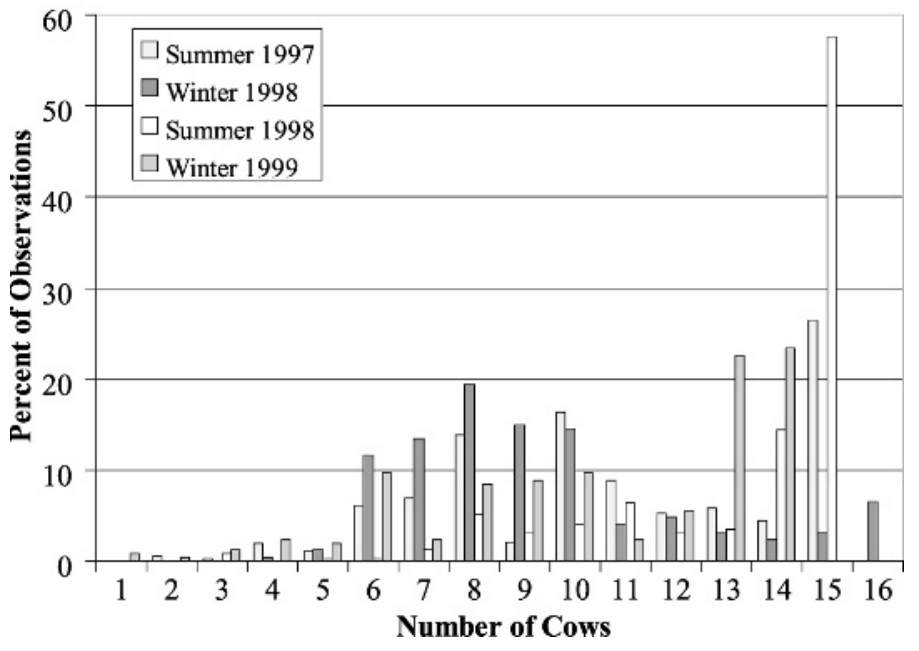

Figure 3. Number of cows in observation periods expressed as a percentage of total number of observation periods. Graph demonstrates effects of season and standing crop on locating animals. Standing crop (given as kilograms of dry matter $\cdot$ ha $^{-1}$ ) for summer $1997=1690$; winter $1998=816$; summer $1998=2387$; winter $1999=1786$.

nearest-neighbor distances decreased. These results are consistent with the findings of Dudzínski et al. (1982), who noted that tighter herd groupings occurred with greater amounts of forage.

Although the cattle in our study often functioned as a single herd unit, there were times when the herd fragmented into smaller subgroups. After we initially identified the subgroup structure, we were able to accurately predict group membership when fragmentation occurred, with the notable exception of independent animals. Takeda et al. (2000) suggested that a natural group for stable life in a communal pasture contained from 3 to 5 cows. In our study, 8 out of 12 subgroups, $67 \%$ were within this range (Table 5); however, we also observed 2 stable groups consisting of 6 animals. Although we also delineated subgroups composed of 2 animals in 2 of our observation series, these animals were usually seen in the company of a larger group or with independent animals. They seldom operated as a group of only 2 animals. The group in the summer of 1997 was composed of 2, 2-year-old heifers that had been born one after the other at the station, whereas the group in the winter of 1998 was composed of 2 Charolais replacement cows purchased 2 years earlier.

Subgroup membership was mainly related to age in our study. Each observation series usually had $\geq 1$ subgroup that contained older cows than the other subgroups. The only exception was in the winter of 1998 , when 9 out of the 16 animals in the unit were 4-years old. In that observation series, 3 of the older animals operated in an independent manner, and another 2 assumed a dominant leadership position in each of the main subgroups. The dominant animals were 5- and 4-years older than most other cows in the subgroups. There was also a 6-year-old animal in 1 of these groups. In 5 of the 12 subgroups identified in our study, the age difference between group members was 1 year or less, whereas the mean age difference between subgroups was 3 years or more. In the winter of 1999,8 out of 14 animals were $>11$ years of age. Two subgroups contained animals in that age class; however, 1 group also contained a 3 -year-old. The third group consisted of younger animals ranging from 3- to 5-years old. Therefore, 9 of our 12 subgroups had an age relationship that we could identify. This result also supports the observations of Honoré and Klopfer (1990) that social structure is based on familiarity of animals. Cows born in the same year are raised with their peers and develop strong associations with each other.

We were not able to correlate any factors to the independent behavior of some animals and believe this is a topic for further research. Field delineation of subgroups in the winter of 1999 was complicated because 2 cows gave birth unexpectedly and stayed near their calves for several days before rejoining the herd. Although we classed 3 animals as independent in their actions for this period, 1 of these had calved before the fourth day of observations and may not have exhibited independent behavior otherwise. In certain instances, independent animals were younger animals (less than 4 years of age) that simply did not show a strong affinity to any particular subgroup but were usually in close proximity to one group or another. In other cases, independent animals were older animals $(>8$ years of age) that were much more inclined to be found grazing alone. Because of the way we selected our cows from a larger herd, animals might exhibit independent actions because they were separated from their closely associated herd mates. This may be more of an issue to younger animals experiencing this for the first time than for older cattle used to the management actions, such as culling or splitting herds for grazing efficiency, which often lead to fragmentation of groups. Often the factor controlling which of the main subgroups was larger and, therefore, the group we followed in our observations, was the number of independent animals that chose to accompany each subgroup. We did not find any relationship between breed of cattle and subgroup membership or independence.

If the independent animals were not included in determining the dominance hierarchy, the most dominant animal in our herd unit was always the oldest or one of the oldest in the group (Table 1). The second and third most-dominant animals were usually the next oldest animals, with some notable exceptions. The third most-dominant animals in the summer of 1998 and in the winter of 1999 were younger animals. In both cases, they were the dominant animals in their respective subgroups and were frequently challenged by older cows in the herd unit, but they maintained their positions throughout the observation series. In the winter of 1999, cow 4096, 5 years of age, was an especially aggressive Black Angus that dominated cows 7 years her senior. However, she never challenged the 2 cows that were higher in dominance. The hierarchal dominance structure for the top 3 positions was linear in 3 of our observation series. Only during the summer of 1997 , did the dominance structure become more complex for the third position. The dominant animals belong to 1 subgroup containing the oldest animals. Cow 471, a Brahman-type at 16 years of age, was 4-years older than the next-oldest cow and was the undisputed dominant animal. A 10-year-old Black Angus was the second mostdominant animal. When they operated as a separate subgroup, 2 cows, age 9 and 10 years, tried to occupy the third position without a clear winner. That structure changed when the cows operated as a single herd unit; then, an independent Hereford, 4 
years of age and one of the few cows to possess a single horn, also struggled to exert dominance. There was no clear winner, so we classified the dominance third position as triadic in nature. Independent animals would sometimes change the dominance structure. In the winter of 1998, when the independent animals 8056 and 8003, both 10-year-olds, were present at the supplement site, they could exert dominance over all the other cows except the dominant cow 9036, a 9-year-old. However, in most cases, they were not with the main herd, and other cows assumed their positions. In our study, agedominance correlations were higher than weight-dominance correlations. These observations match those of other researchers (Beilharz and Zeeb 1982, and Oberosler et al. 1982) who found dominance related to age in mixed-age herds. Most dominant animals in our study were Black Angus or Black Baldy, but 2 Brahmans, 2 Herefords, and a mixed-breed cow also occupied dominant positions.

The association software, ASSOC1, worked well at delineating certain subgroups outright, but it was often hard to tell the difference between other subgroups and independent animals based on association statistics alone. ASSOC1 would always accurately delineate the subgroup on which we had the most observational data, i.e., the subgroup we followed most often. Other subgroups might be accurately delineated by the program or, quite often, they would simply appear at a higher spatial threshold as part of a larger group. For example, in summer of 1998 (Fig. 2), a subgroup delineated at a spatial threshold of $30 \mathrm{~m}$ matched one of our field-delineated subgroups of 5 animals. At a spatial threshold of $35 \mathrm{~m}$, another subgroup of 3 animals matching our field delineation was also recognized. However, the third field-delineated subgroup of 5 animals was recognized by ASSOC1 as a being a part of the larger group at the $35 \mathrm{~m}$ threshold. The 2 independent animals, cows 4154 and 2043, were the last to be incorporated into the herd group at a threshold of $50 \mathrm{~m}$. In other cases, such as summer 1997 (Fig. 1), it was impossible to sort out when an independent animal, such as cow 3104, was delineated as part of the larger group vs. cow 0012, who was a member of another subgroup. We feel this lack of subgroup delineation might not be a problem with the software but may be an artifact of our observation techniques, i.e., following the group containing the most individuals. Delineation might not be an issue using different methods for acquiring spatial data, such as GPS collars. Our main problem with the ASSOC1 delineations was determining at what spatial threshold a distinct subgroup was defined. We benefited greatly from our observation-based delineation to guide us with the delineations generated by the association program.

Where ASSOC1 excelled was the quantification of time that animals were in close proximity. Often animals showed examples of close associations. For example, in summer 1997, cows 0471 and 7113 were within $30 \mathrm{~m}$ of each other $73 \%$ of the time and within $75 \mathrm{~m}, 90 \%$ of the time. In summer 1998, cows 9084 and 0596 were within $20 \mathrm{~m}$ of each other $68 \%$ of the time and within $50 \mathrm{~m}$, nearly $90 \%$ of the 6 -day observation series. In part, these close summer associations were based on thermoregulatory actions because the cows rested in a compact group under shade trees for about 8.7 hours each day or for about $50 \%$ of our daylight observations. Winter observations produced a slightly different pattern for 2 main reasons. The daylight period was shorter, and therefore, there were fewer individual observations. Also, the cows did not necessarily seek shade and, if they did, only rested for $1-3.5$ hours a day or $10 \%-35 \%$ of the time. We, therefore, expected to see looser associations and a broader spatial distribution in winter (Shiyomi and Tsuiki 1999). Even with these differences, in winter 1999, cows 0712 and 7455 were within $25 \mathrm{~m}$ of each other $75 \%$ of the time and within $100 \mathrm{~m}$ of each other, $90 \%$ of the time. Interestingly, in all cases, closely associated animals were the most dominant animal and the second, or in the case of summer 1997, third most-dominant animal in the herd unit. These relationships led us to hypothesize that the close associations may not necessarily indicate the affinity of one animal for another but might be an indication of the pattern of dominant animals in the herd. Other researchers (Wagnon et al. 1966; Stricklin 1983) have reported that dominant animals occupy the center position in a herd of loafing cattle. Syme et al. (1975) noted that high-ranking cows allowed other cows to approach closer more frequently than lower ranking animals. Stricklin (1983) reported that animals in the group center had a lower mean distance to all other group members and demonstrated greater group cohesiveness in spacing characteristics. Stricklin et al. (1976) also noted a trend for middle-ranking animals to space themselves further from the group center and from first nearest neighbors than higher ranking cattle. We believe this to be an area deserving further research.

\section{MANAGEMENT IMPLICATIONS}

We see a time in the not-too-distant future when GPS technology will be miniaturized and low-cost enough to be incorporated into something like an ear tag placed on all animals in a herd. Our research indicates that spatial analysis of such data may allow ranchers and land managers to quantify forage conditions based on nearest-neighbor distances between animals, perhaps reducing the need for physical measurements, such as clipping or ocular estimation. This capability will allow producers to better modify stocking rate for optimum production while lessening undesirable grazing effects on the land base. Spatial-temporal analysis might allow ranchers to determine the social structure of the herd, both subgroup membership and dominance hierarchy, to aid in decisions regarding herding, selective culling, and feeding of supplements. Finally, the concept of a stable natural group size for a site (more likely a terrain-type) might be incorporated into the techniques used to rear young animals to maturity to create a more manageable herd unit.

\section{CONCLUSIONS}

A cattle herd is generally created by ranchers when they choose animals to graze a pasture or rangeland. These animals often graze together and have similar activity patterns, yet within the herd can be observed individuals or, more frequently, subgroups that operate independently. Management actions are more likely to be effective if the social structure and 
functioning of the herd unit is understood and incorporated into management decisions.

The organization of a herd of cows in our study consisted of subgroups, which formed a herd unit occasionally. The size of a stable natural group for our site ranged between 3 and 6 animals. The proximity to neighboring individuals and subgroups appeared to be a function of available forage. When forage was abundant, herds were more compact and animals grazed closer together. When forage was limited in quantity, herds fragmented into subgroups that are more independent.

The association software used in our analysis provided results that, in most cases, matched our field observations. The ASSOC1 program accurately recognized most subgroups and usually defined dominant animals as the most closely associated animals. However, defining appropriate threshold distances used to identify animal subgroups would be problematic without field observations. The last animals incorporated into herd groupings were usually animals that exhibited independent actions. How to handle individual animals that delineate overlapping herd templates is still a question. In our observations, these animals acted as connections between distinct subgroups and helped define the herd unit. This is also an area for further research. In general, we think that association matrices and association recognition programs like ASSOC1 will facilitate social interpretation of spatial data collected with GPS-collared animals.

\section{ACKNOWLEDGMENTS}

The authors wish to thank Dr. Keith Weber, Idaho State University, for providing us with his ASSOC1 software, for review of the manuscript in its initial form, and for suggestions of analytical procedures. We also wish to thank Dennis Jones, manager of the San Joaquin Experimental Range, for selecting and handling of research animals during the study. We would further like to thank the reviewers, both anonymous and known, for their excellent suggestions on how to improve this paper.

\section{LITERATURE CITED}

BallEY, D. W. 1995. Daily selection of feeding areas by cattle in homogeneous and heterogeneous environments. Applied Animal Behavioral Science 45:183-200.

Balley, D. W., J. E. Gross, E. A. Laca, L. R. Rittenhouse, M. B. Coughenour, D. M. Swift, AND P. L. Sims. 1996. Mechanisms that result in large herbivore grazing distribution patterns. Journal of Range Management 49:386-400.

Bailey, D. W., D. D. Kress, D. C. Anderson, D. L. Boss, and E. T. Miller. 2001. Relationship between terrain use and performance of beef cows grazing foothill rangeland. Journal of Animal Science 79:1883-1891.

Balley, D. W., And G. R. Welling. 2007. Evaluation of low-moisture blocks and conventional dry mixes for supplementing minerals and modifying cattle grazing patterns. Range Ecology and Management 60:54-64.

Beilharz, R. G., And K. Zeeb. 1982. Social dominance in dairy cattle. Applied Animal Ethology 8:79-97.

Bentley, J. R., and M. W. Talbot. 1951. Efficient use of annual plants on cattle ranges in the California foothills. Washington, DC: US Department of Agriculture Circular $870.51 \mathrm{p}$.

Bryant, L. D. 1982. Response of livestock to riparian zone exclusion. Journal of Range Management 35:780-785.

Buechner, H. K., F. C. Craighead, JR., J. J. Craighead, and C. E. Cote. 1971. Satellites for research on free roaming animals. BioScience 21:1201-1205.
Clark, P. E., D. E. Johnson, M. A. Kniep, P. Jermann, B. Huttash, A. Wood, M. Johnson, C. McGillivan, and K. Titus. 2006. An advanced, low-cost, GPS-based animal tracking system. Range Ecology and Management 59:334-340.

Coughenour, M. B. 1991. Spatial components of plant-herbivore interactions in pastoral, ranching, and native ungulate ecosystems. Journal of Range Management 44:530-542.

Dudzínski, M. L., W. J. Müller, W. A. Low, And H. J. SchuH. 1982. Relationship between dispersion behaviour of free-ranging cattle and forage conditions. Applied Animal Ethology 8:225-241.

Eversole, D. E., M. F. Browne, J. B. Hall, and R. E. Dietz. 2000. Body condition scoring beef cows. Blacksburg, VA: Virginia Polytechnic Institute and State University, Virginia Cooperative Extension Publication 400-795. 6 p.

GanSKOPP, D. C. 2001. Manipulating cattle distribution with salt and water in large arid-land pastures: a GPS/GIS assessment. Applied Animal Behavior Science 73:251-262.

Gillen, R. L., W. C. Krueger, and R. F. Miller. 1984. Cattle distribution on mountain rangeland in northeastern Oregon. Journal of Range Management 37:549-553.

Gravetter, F. J., and L. B. Wallnau. 1985. Statistics for the behavioral sciences. St. Paul, MN: West Publishing Company. 801 p.

HaRRIS, N. R. 2001. The effects of vegetation, topography and weather on cattle distribution in the California foothills [dissertation]. Corvallis, OR: Oregon State University. 199 p.

Honoré, E. K., and P. H. Klopfer. 1990. A concise survey of animal behavior. San Diego, CA: Academic Press Inc. 186 p.

Howery, L. D., F. D. Provenza, R. E. Banner, and C. B. Scott. 1996. Differences in home range and habitat use among individuals in a cattle herd. Applied Animal Behavioral Science 49:305-320.

Hull, J. L., G. P. Lofgreen, and J. H. Meyer. 1960. Continuous versus intermittent observations in behavior studies with grazing cattle. Journal of Animal Science 19:1204-1207.

Kauffman, J. B., W. C. Krueger, and M. Vavra. 1983. Effects of late season cattle grazing on riparian plant communities. Journal of Range Management 36:685-691.

LAzo, A. 1994. Social segregation and the maintenance of social stability in a feral cattle population. Animal Behaviour 48:1133-1141.

MalecheK, J. C., And B. M. Smith. 1976. Behavior of cows in response to winter weather. Journal of Range Management 29:9-12.

Marlow, C. B., and T. M. Pogacnik. 1986. Cattle feeding and resting patterns in a foothill riparian zone. Journal of Range Management 39:212-217.

Mench, J. A., J. C. Swanson, and W. R. Strickiln. 1990. Social stress and dominance among group members after mixing beef cows. Canadian Journal of Animal Science 70:345-354.

Moorefield, J. G., And H. H. Hopkins. 1951. Grazing habits of cattle in a mixedprairie pasture. Journal of Range Management 4:151-157.

Oberosler, R., C. CarenzI, and M. Verga. 1982. Dominance hierarchies of cows on Alpine pastures as related to phenotype. Applied Animal Ethology 8:67-77.

Peterson, R. A., and E. J. Woolfolk. 1955. Behavior of Hereford cows and calves on short grass range. Journal of Range Management 8:51-57.

Pinchak, W. E., M. A. Smith, R. H. Hart, and J. W. Waggoner, JR. 1991. Beef cattle distribution patterns on foothill range. Journal of Range Management 44:267-275

Porath, M. L., P. A. Momont, T. Delcurto, N. R. Rimbey, and J. A. Tanaka. 2002. Offstream water and trace mineral salt as management strategies for improved cattle distribution. Journal of Animal Science 80:346-356.

Reinhardt, V., And A. Reinhardt. 1981. Cohesive relationships in a cattle herd (Bos indicus). Behaviour 77:121-151.

Roath, L. R., and W. C. Krueger. 1982a. Cattle grazing influence on a mountain riparian zone. Journal of Range Management 35:100-103.

Roath, L. R., And W. C. Krueger. 1982b. Cattle grazing and behavior on a forested range. Journal of Range Management 35:332-338.

SAS Institute Inc. 1998. SAS/STAT user's guide. Version 6.03. Cary, NC: SAS Institute Inc. $711 \mathrm{p}$.

SATO, S. 1982. Leadership during actual grazing in a small herd of cattle. Applied Animal Ethology 8:53-65. 
Schein, M. W., And M. H. Fohrman. 1955. Social dominance relationships in a herd of dairy cattle. The British Journal of Animal Behaviour 3:45-55.

Senft, R. L., L. R. Rittenhouse, and R. G. Woodmansee. 1983. The use of regression models to predict spatial patterns of cattle behavior. Journal of Range Management 36:553-557.

Senft, R. L., M. B. Coughenour, D. W. Balley, L. R. Rittenhouse, 0. E. Sala, and D. M. SwIFt. 1987. Large herbivore foraging and ecological heirarchies. Bioscience 37:789-799.

ShIYoma, M., AND M. TsuIKI. 1999. Model for the spatial pattern formed by a small herd in grazing cattle. Ecological Modeling 119:231-238.

SMIтH, M. S. 1988. Modeling: three approaches to predicting how herbivore impact is distributed in rangelands. Las Cruces, NM: New Mexico Agricultural Experiment Station Research Report 628. 16 p.

Sowell, B. F., J. C. Mosley, and J. P. G. Bowman. 1999. Social behavior of grazing beef cattle: Implications for management. Proceedings of the American Society of Animal Sciences 1-6.

StrickLin, W. R. 1983. Matrilinear social dominance and spatial relationships among Angus and Hereford cows. Journal of Animal Science 57:1397-1405.

Stricklin, W. R., L. L. Wilson, and H. B. Graves. 1976. Feeding behavior of Angus and Charolais-Angus cows during summer and winter. Journal of Animal Science 43:721-732.

StrickLIN, W. R., AND H. W. Gonyou. 1981. Dominance and eating behavior of beef cattle fed from a single stall. Applied Animal Ethology 7:135-140.
Stricklin, W. R., and J. A. Mench. 1987. Social organization. Veterinary Clinics of North America: Food Animal Practice 3:307-322.

Syme, L. A., G. J. Syme, T. G. Waite, and A. G. Pearson. 1975. Spatial distribution and social status in a small herd of dairy cows. Animal Behaviour 23:609614.

Takeda, K., S. Sato, and K. Sugawara. 2000. The number of farm mates influences social and maintenance behaviours of Japanese Black cows in a communal pasture. Applied Animal Behavioral Science 67:181-192.

Tate, K. W., E. R. Atwill, M. R. George, N. K. McDougald, and R. E. Larsen. 2000. Cryptosporidium parvum transport from cattle fecal deposits on California rangelands. Journal of Range Management 53:295-299.

VAN SOEST, P. J. 1982. Nutritional ecology of the ruminant. Corvallis, OR: 0 \& B Books, Inc. 344 p.

Wagnon, K. A. 1963. Behavior of beef cows on a California range. Sacramento, CA: California Agricultural Experiment Station Bulletin 799. 58 p.

WaGnon, K. A. 1967. Use of different classes of rangeland by cattle. Sacramento, CA: California Agricultural Experiment Station Bulletin 838. 16 p.

Wagnon, K. A., R. G. Loy, W. C. Rollins, and F. D. Carroll. 1966. Social dominance of a herd of Angus, Hereford, and Shorthorn cows. Animal Behaviour 14:474-479.

Weber, K. T., M. Burcham, and C. L. Marcum. 2001. Assessing independence of animal locations with association matrices. Journal of Range Management 54:21-24. 